\title{
doi.org/10.46291/ISPECIJSSHvol4iss4pp271-284
}

\section{After Covid-19 New Payments Methods in International Trade}

\author{
Selminaz ADIGÜZEL \\ Assistat Professor, Harran University Siverek Applies Sciences Faculty \\ International Trade and Logistics Departments \\ sadiguzel $\odot$ harran.edu.tr \\ ORCID NUMBER 0000-0002-6808-2888
}

\begin{abstract}
The Corona epidemic that started about in 2019 brought changes in the fields of economy, politics and education. Significant changes have occurred in the forms of payment and delivery, which is one of the important issues in international trade.Incoterms 2020, after ICC announced on September 10, 2019, Incoterms International Trade Terms) investigated the responsibilities of cross-border merchants (exporter) and buyers (importer) for the delivery of tradable goods, to investigate new forms of payment after the Covid 19 outbreak. Information about payment methods in international trade is given.In the research, the literature search was done and after 2020 Corona virus, researches and payment methods in the world were examined. According to the research result, after the Sars virus, developed countries established their digital infrastructures and made their preparations about 20 years ago and made their commercial infrastructures suitable for remote trade. He prepared the payment methods for the establishment of the ICC Digital infrastructure. Economic stagnation and a fall in GDP are related to a decrease in demand. China, one of the countries where the virus started, was not caught in Corona. The rich continue to be rich, the poor still become poor.
\end{abstract}

Keywords: Corona 19 Pandemic, Economy, International trade, payment and delivery types ICC, Incoterms.

\section{Covid 19 Salgını Sonrasında Yeni Ödeme Şekilleri}

\section{Özet}

2019 yılında başlayan Corona salgını, ekonomi, siyaset, eğitim alanlarında değişiklikler meydana getirdi. Uluslararası ticaretin önemli konularından biri olan ödeme ve teslim şekillerinde önemli değiş̧iklikler meydana gelmiştir. Incoterms 2020, ICC tarafindan 10 Eylül 2019'da duyurulduktan sonra Incoterms Uluslararası Ticari Terimler) sınır ötesi ticaret yapan satıcı (ihracatçı) ve alıcıların (ithalaţ̧ı), ticarete konu malların teslimi konusundaki sorumluluklarını araştırmak Covid 19 salgını sonrasında yeni ödeme şekillerini araştırmak amacıyla yazdığımız bu araştırmada uluslararası ticarette ödeme ş̧ekilleri hakkında bilgi verilmiş̧ir. Araştırmada literatür taraması yapılarak 2020 Corona virüsü sonrasında dünyada yapılan araştırmalar ve ödeme şekilleri incelenmiştir. Araştırma sonucuna göre sars virüsü sonrasında gelişmiş ülkeler dijital alt yapılarını kurarak yaklaşı 20 yıl önceden hazırlıklarını yaparak ticari alt yapılarını uzaktan ticarete uygun olarak hazırlıklarını yapmışlardır. ICC Dijital alt yapının kurulması için ödeme şekillerinin hazırlı̆̆ını yapmıştır. Ekonomik durgunluk ve GSYïH 'da düşme, talebin düşmesi ile alakalıdır. Virüsün başladığı ülkelerden Çin, Coronaya tedbirsiz yakalanmamıştır. Zenginler yine zengin, fakirler yine fakir olmaya devam etmektedir.

Anahtar Kelimeler: Corona 19 Pandemi, ekonomi, uluslararası ticaret, ödeme ve teslim şekilleri ICC, Incoterms.

Year 4/ 2020, Volume-4, Issue-4 | WWW.ispecjournal.org 


\section{INTERNATIONAL PAYMENT METHODS AFTER CORONA 19}

With the Corona epidemic, II. The deepest global recession has been experienced since World War II. COVID-19 is a pandemic that is 9 times stronger than the lethal force of SARS. On 5 March 2020 worldwide, the countries most affected by the disease are the USA, China, Japan, Germany, England, France and Italy. The number of sovereign countries in the world that are members of the United Nations is 195. Since the Corona outbreak is seen in 170 countries, the spread of the virus is more than $87 \%$. Since the Covid epidemic caused fatal consequences, protective measures were taken and commercial businesses were closed. The global economy has experienced 14 global stagnations since 1870 :

Graphic 1 Economic recession
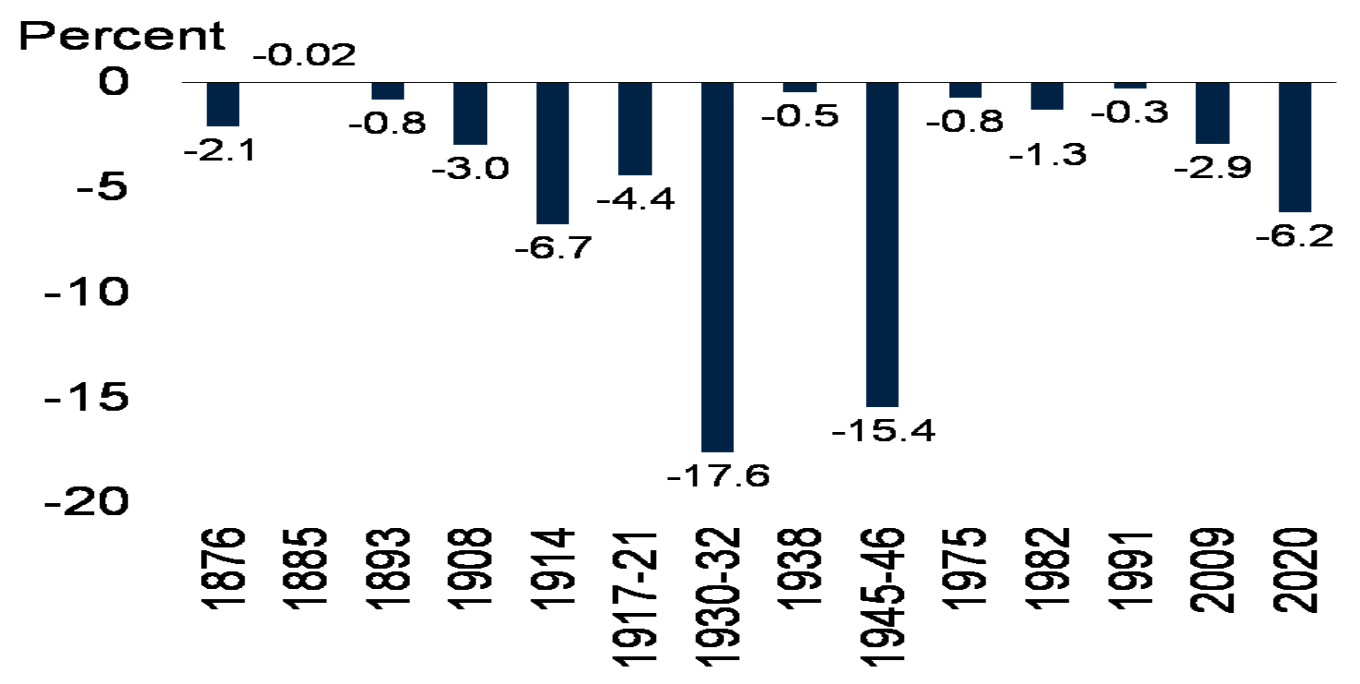

Source World Bank 2020

According to the data of the World Bank, there has been a contraction in gross domestic product (GDP) per capita since 1870. The economic recession in 2020 is at the level of 1 World War with a ratio of -6.2 . 


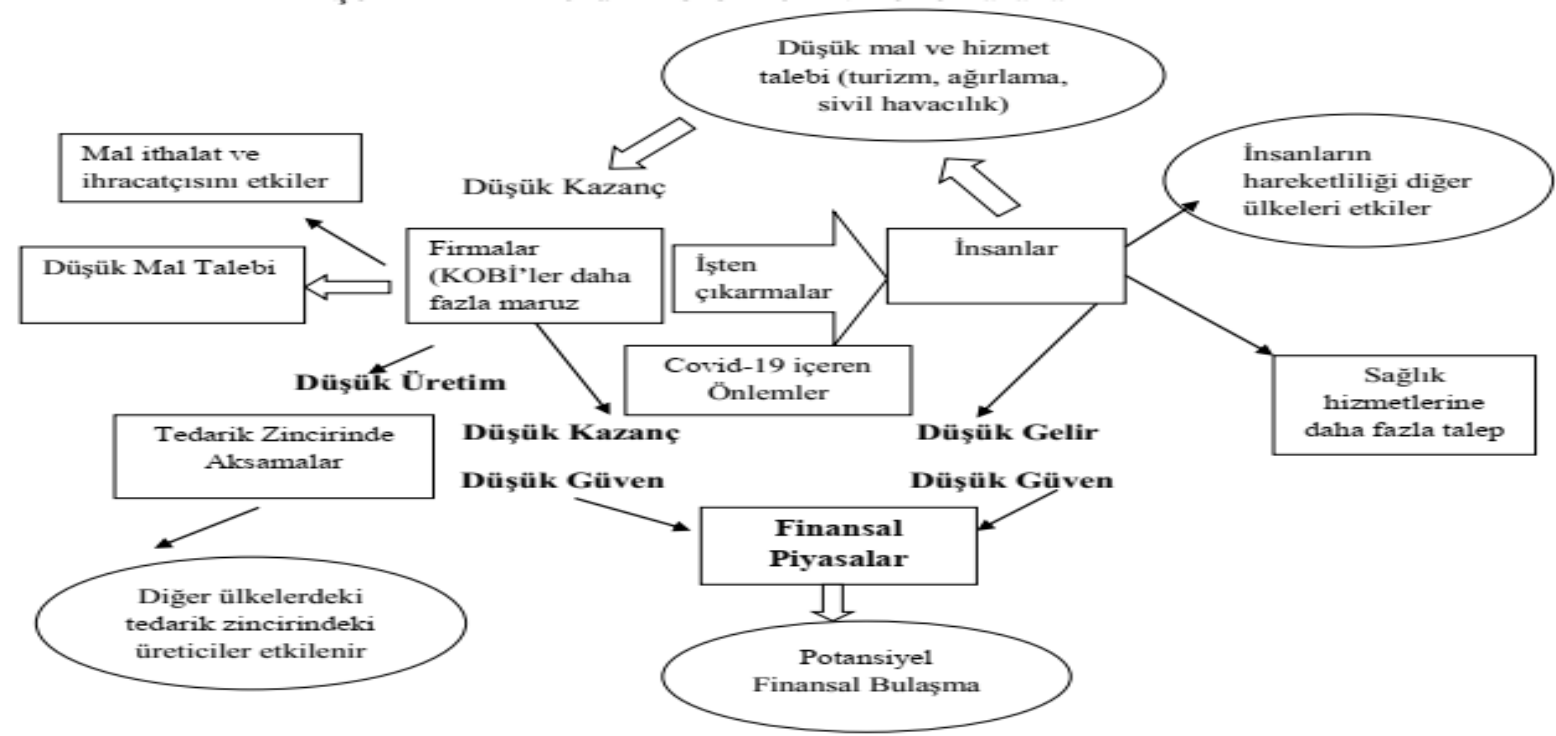

Figure 1. Covid-19's Channels for Affecting Economies

Source: ESCAP, (EconomicandSocialCommissionforAsiaandthe Pacific (2020, 2). Https: //www.unescaporg/sites/default/files/COVID\%20_Report_ESCAP.pdf. Access Date: 30.04.2020.

Effects of Covid 19, it affects the import and export of commodities. As can be seen in the figure, it is seen as low supply of goods, disruptions in the supply chain, layoffs, low service demand, increased demand for health services, low trust and high digital gain.

Delivery and payment methods have changed in international trade. The countries that establish the internet network structure in foreign trade with digital inequality and the countries that cannot fully establish the internet infrastructure are divided into two. Inequality has begun to appear between the countries that have prepared their networks in international trade and the countries that have not built their networks. One of the most important business choices of 2020 was the strengthening of internet access networks.

Corona virus has changed the course of international trade as it is a sudden situation. When editing the content of ICC International commercial contracts, each of the rules appears to contain a clause on the concept of force majeure. Corona virus outbreak is also a force majeure .. pandemic COVID-19 can be accepted as a force majeure according to ICC rules (Commerce I. C. 2020). 
Graph 2. The slowing global payment revenue

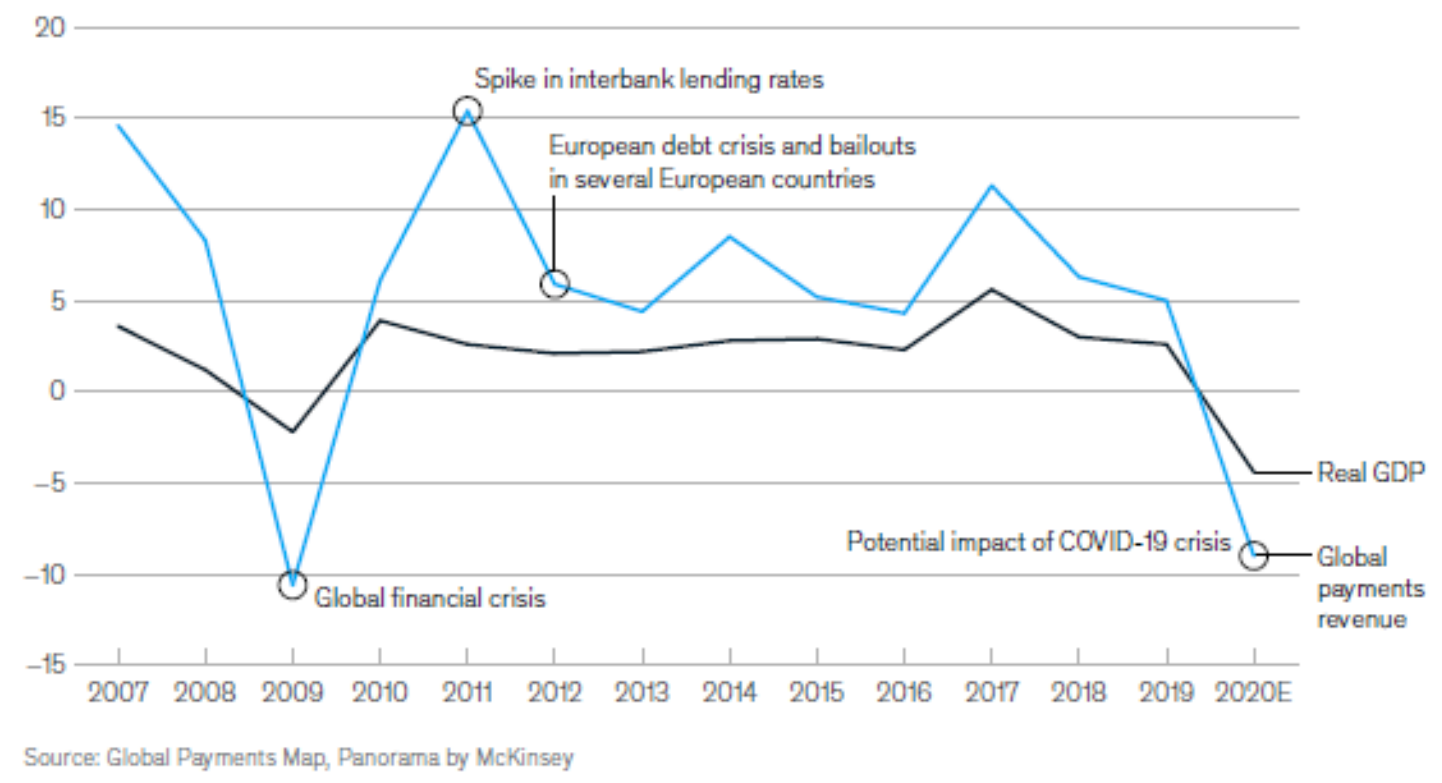

The slowing global payment revenue growth is expected to cost the payment sector in 2020 from $\$ 165$ billion to $\$ 210$ billion.

Chart 3 GDP ratio in 2020
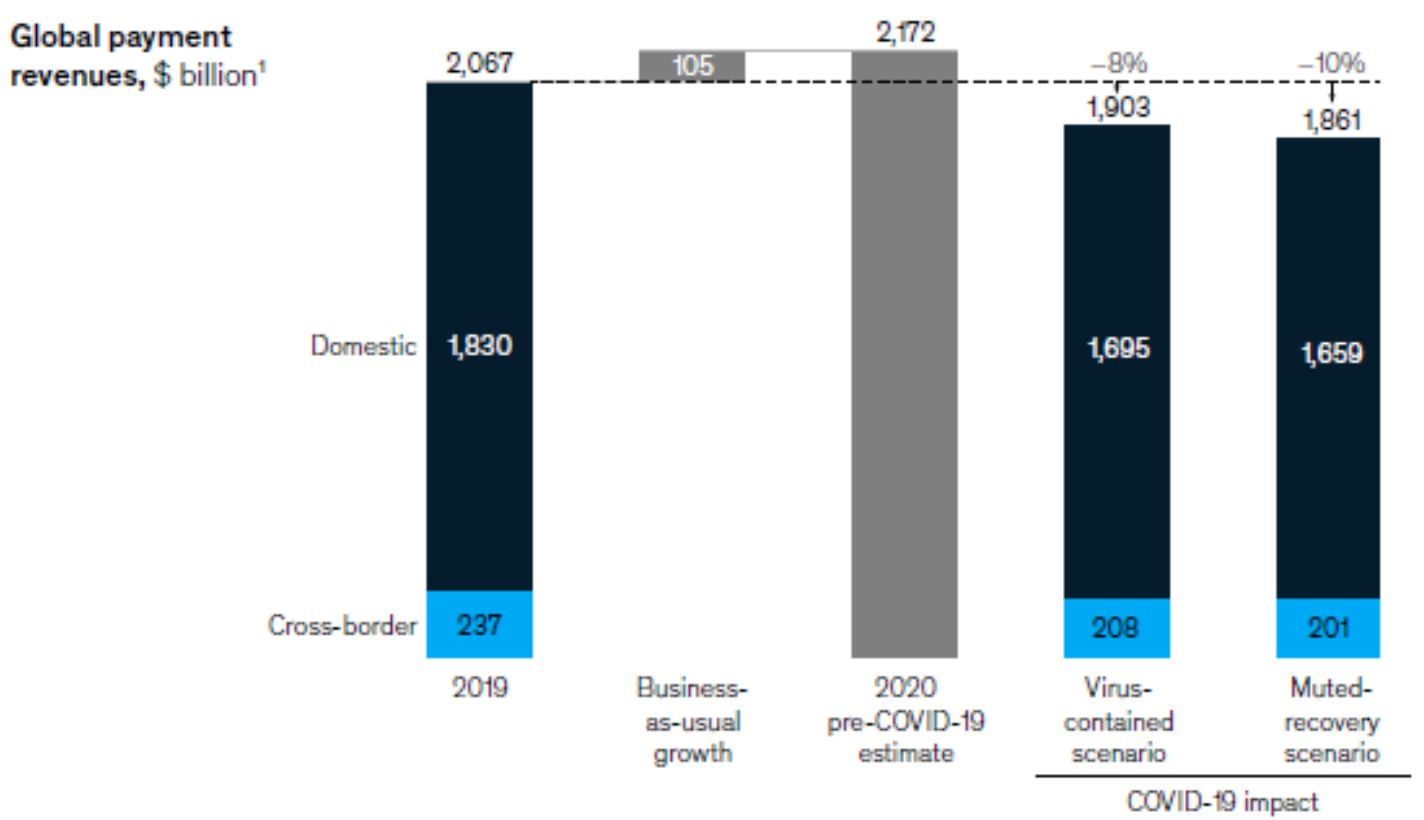

Source World Bank, 2020. 
Global GDP will drop by 1.5 percent in 2020, and it is expected that it will result in a drop of around $\$ 165$ billion, with an estimated 8 percent lower in revenue than in 2019. Against the $\$ 1.9$ trillion base (Chart 2). A second, more pessimistic scenario3 A quiet recovery is predicted, leading to a global trade level and shrinking large economies, with the virus's revival in China and its spread to the United States and Europe.

In this scenario, global GDP will shrink 4.7 percent in 2020, which can result in about 10 to 12 percent of precision levels, exceeding $\$ 210$ billion in global payments revenue.

\subsection{Payment Methods (Collection Press) and Application Steps Based on Collectible Basis in International Trade}

In the world of e-commerce, in most cases, the customer cannot see the physical product while the transaction and payment are made electronically.

Electronic payment systems (EPS) are integrated hardware and software systems that allow customers to purchase goods and services online.

According to the "Global Digital Report of 2020" jointly organized by We Are Social and Hootsuite (https://www.fundalina.com/2020-yili-global-diigital-raporu/, 2020)

Taken globally, 60 percent of the world's population is online. Being successful in the global market, increasing sales, making payments on time requires a whole set of rules that exporters (sellers) and importers (foreign buyers) must follow. One of these rules is the forms of payment.

Figure 2. Payment Types in International Trade

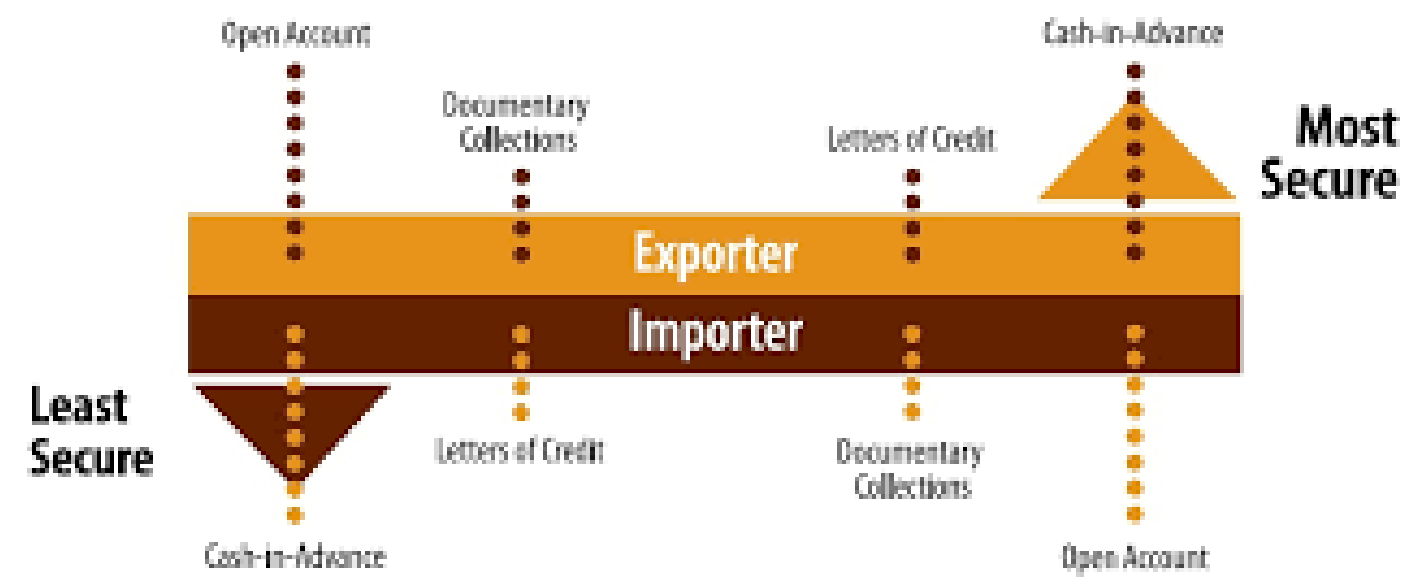

Source(https://www.letterofcredit.biz/index.php/2019/02/20/payment-methods-ininternational-trade/, 2020 .

Year 4/ 2020, Volume-4, Issue-4 | WWW.ispecjournal.org 
Payment methods performed in international trade are cash, cash against goods, cash against documents, cash against credit cards, cash against credit cards. International payment transactions made through banks are collected. Since the payment methods are carried out on paperwork, the problem of being approved on paper before and after the corona epidemic has arisen. BPO (Bank Payment Obligation) A new form of payment and financing is observed in foreign trade. If the risk increases for the buyer and the seller in terms of payment against goods, documents against cash, letters of credit etc. that are mostly used in foreign trade, operational difficulty and cost also increase. The last solution produced by the banking system; BPO (Bank Payment Obligation) option. The Bank Payment Obligation system not only reduces risk but also reduces operational burden and cost. Mixing the letter of credit and the corresponding of the goods is a transaction that provides ease of operation. It is a form of payment made online by the central system, not through documents similar to letters of credit. The seller sends the documents of the transaction to the buyer. It informs the beneficiary bank about the data in the documents. The bank doesnt have to transfer any documents. Beneficiary Bank uploads the data to the BASELINE system. At this stage, the buyer notifies the Responsible Bank as the data of the transaction. The liable bank uploads this data to the same BASELINE system. If the conditions in the database match the initial data, the liable bank undertakes to pay. Thus, foreign trade is carried out in a faster and safer system. In terms of financing, Lehdar Bank offers the Seller the opportunity of financing before or after the shipment. The assurance of the beneficiary bank stems from the liable bank guaranteeing payment when the conditions in the database are compatible. The liable bank doesn't necessarily have to be the bank of the buyer, and a third bank can be used within this system. However, Lehdar Bank must have been the bank of the seller (Unions, 2020, p. 1). New payment method of the banks It is seen that the working group of the ICC is compatible with the digital payment method over the internet. The World Sars virus has prepared infrastructure for keeping the economy alive by focusing on digitalization When cripto money first appeared, it was criticized by countries in international trade. In some countries it has not been accepted as the official currency, with the concern that blockchain will be used for money laundering. However, after the corona epidemic, digital money started to attract attention. As a result of the coronavirus outbreak, many things in the world have changed, as well as the forms of payment. While nearly $50 \%$ of global shoppers are in the form of digital payments, this rate increased even more after the epidemic. "E-Wallets"and contactless cards are forms of payment that are seen on a global scale, using less cash and shopping more online. Global Online Payments Industry Report 2020 In a well-published international survey, three-quarters of respondents stated that it is cleaner to make a contactless payment (Global Online Payments Industry Report 2020- Payment Behavior as a Result of the Coronavirus COVID-19 Outbreak In international payments, UK buyers preferred debit cards while those in Italy preferred digital wallets like PayPal. According to a survey dated April 2020, payment security is the most important criterion for online shoppers. When the literature is analyzed, there are many sources related to foreign trade payment methods. Foreign trade has more structural difficulties compared to domestic trade, and the competition is increasing day by day, making payment methods important. As foreign trade increases, 
payment of trust with letters of credit has started to be preferred because the problem solves (Yurtsever, 2010, p. 856).

\section{International Chamber of Commerce}

The potential for digital transformation through blockchain, the Internet of Things (IoT), Artificial Intelligence and other digital developments benefits banks and their customer base worldwide.

These improvements in trade finance proposals have the potential to reduce costs and encourage greater economy in global finance. Digitized trade has been widely adopted, especially due to the advantages it provides to small and medium-sized enterprises (SMEs).

Besides the advantages of digital commerce, it also has some limitations. To overcome these obstacles, ICC in 2017 established the ICC Banking Commission, the Digitalization Working Group in Trade Finance, as a coordination body to carry out work on digitization in trade finance. The "E-compliance working Group of ICC rules, first of all, to ensure that banks accept all existing ICC rules, electronic documents and data instead of just paper documents.

Rleased UCP version 2.0 and URC version 1.0. (ICC, 2020) e UCP version 2.0 and URC version 1.0 include the following information about Uniform Rules for Digital Trade Transactions:

1. Uniform Rules for Digital Trade Transactions (URDTT). The aim of URDTT is to develop a high-level framework that outlines obligations, rules and standards for digitizing trade finance.

2. Adopting FinTech This workflow is to develop a set of minimum standards for digital connectivity for technology service providers across the legal, responsibility, information security and technology (part model contract / part technical standard document) to ensure the acceleration of the link between supply chain partners. it is compulsory.

3. Laws and legal framework on the use of data and electronic documents The Working Group also conducted a legal questionnaire to understand third parties' rights under e-Invoices and E-Invoices.

The aim was to provide guidance on the acceptance of documents that banks use as security for trade financing transactions (eg Bill of Lading). The current focus is on the adoption of the UNCITRAL Electronic Transferable Records Model Act ("MLETR"), as well as the advocacy of WTO's multilateral negotiations on the commercial aspects of electronic commerce (ICC, 2020).

\section{Commercialization}

The Working Group has published a roadmap to promote digital digital commerce.

Year 4/ 2020, Volume-4, Issue-4 | WWW.ispecjournal.org 
This roadmap highlights individual actions that can be taken by the ICC, the banking industry and governments. This work is carried out by the ICC national and regional offices, known as national committees. It contains information on key countries in global trade and trade corridors to adopt recommended recommendations on the roadmap. . The reasons for digitalization are uncertainty, antiquity, absence of standards, limited access to finance, bureaucratic barriers, and correspondence. In response to the market need, ICC launched the ICC Digital Trade Standards Initiative (DSI). A common cross-sectoral work is underway to ensure the standardization of digital commerce. It covers only $25 \%$ of the global e-commerce payment methods of systems such as Visa and MasterCard. For example; Visa and MasterCard's share of payment in China appears to be only 3\%. The methods that offer more innovative and faster solutions among e-export payment methods are rapidly becoming widespread. It is now known to many that the payment methods vary greatly from region to region. For example, unlike China and the USA, bank transfer method is widely preferred as an online payment method in Germany. However, more than half of the payments made in the USA are made with credit cards. (https://worldef.net/blog/sinirotesi-odeme-yontemleri/, 2020). After Corona, most banks and financial services companies have taken quick action to protect both their customers and employees (MC CKinsey Company Financial, 2020). Payment systems have proven to be durable and reliable, as in previous crises. One of the challenges faced by companies in the 21 st century is their imperative to compete (Görgün, 2

019, p. 149).

The stability of the systems is important for both payments and securities after the corona. Payment systems have proven to be durable and reliable, as in previous crises. Payment systems and providers, which enable companies and their customers to transfer funds in exchange for goods and services, are preferred because they continue to gain a high level of trust from the public. The quarterly GDP may fall by 35 to 40 percent in the second quarter of 2020, and the financial outlook of the payment industry shows that this uncertainty is reflected in the short term. The increase in income in global payments is expected to be low due to the low production and demand. Instead of growing by 6 percent in the 2019 global payment report, the activity is projected to fall by 8 to 10 percent of total revenues. After the Corona epidemic, digital payments allowed people to access products and services while in quarantine or social distances. China, which was in danger of the Sars epidemic in 2003, has prepared its economy for the future epidemic by strengthening its digital economy infrastructure.

The identification system, which is an important element in the digital economy, uninterrupted internet access, is a reliable way to make money in digital formats, and is important for the development of digital payments. The factor that keeps the economy afloat during the coronavirus epidemic is that digital payments are working because they reduce human-to-human contact with the virus. Contactless digital payments at the point of sale, such as face recognition, Quick Response (QR) codes or near field communication (NFC), can reduce the likelihood of the virus spreading to others through cash exchange The stability of

Year 4/ 2020, Volume-4, Issue-4 | WwW.ispecjournal.org 
the systems is important for both payments and securities after the corona. Payment systems have proven to be durable and reliable, as in previous crises. Payment systems and providers, which enable companies and their customers to transfer funds in exchange for goods and services, are preferred because they continue to gain a high level of trust from the public.

The quarterly GDP may fall by 35 to 40 percent in the second quarter of 2020, and the financial outlook of the payment industry shows that this uncertainty is reflected in the short term. The increase in income in global payments is expected to be low due to the low production and demand. Instead of growing by 6 percent in the 2019 global payment report, the activity is projected to fall by 8 to 10 percent of total revenues. After the Corona epidemic, digital payments allowed people to access products and services while in quarantine or social distances. China, which was in danger of the Sars epidemic in 2003, has prepared its future epidemic economy by strengthening its digital economy infrastructure. The identification system, which is an important element in the digital economy, uninterrupted internet access, is a reliable way to make money in digital formats, and is important for the development of digital payments. The factor that keeps the economy afloat during the coronavirus epidemic is that digital payments are working because they reduce human-to-human contact with the virus. Contactless digital payments at the point of sale, such as face recognition, Quick Response (QR) codes or near field communication (NFC), can reduce the likelihood of the virus spreading to others through cash exchange. Digital payments limit face-to-face transactions and enable consumers to purchase the necessary conditions from the comfort of their homes. Increasing e-commerce initiatives also help small businesses maintain their revenue streams for an indefinite period of time. Online payments, incentive funds provide consumers with quick access to money. For example, local governments in China have distributed WeChat Pay to encourage emergency spending.

China, which has cash money, maintained the quarantines. According to the People's Bank of China (PBOC), online non-bank online payment platforms in China processed RMB 250 trillion, about \$35 trillion, indicating the widespread adoption of the platforms. The most important foreign exchange-earning transactions are exports (Görgün, 2020, p. 17). When we look at the EU, in 2020, total non-EU trade (import + export) decreased from $€ 252$ billion to $€ 228$ billion compared to January 2020. The following is observed in the exports made with five trading partners; The highest trade declines continued with Switzerland (-8.5\%) and China $(-7.1 \%)$, followed by Russia $(-6.8 \%)$, the UK $(-6.2 \%)$ and the United States $(-4.2 \%)$.

Imports from these five main partners also fell during this period. However, the decline in Switzerland (-1.2\%) and the United States (-2.6\%) is smaller than Russia (-8.2\%), China ($10.9 \%$ ) and especially England (-17.0\%). (Effect of COVID-19 on EU International Commodity Trade, 2020)

Chart 45 Main Trade Partners in İnternational Trade of the EU 


\section{EU imports and exports of goods with 5 main trade partners \\ (EUR billion, seasonally adjusted, January 2020 - March 2020)}

EXPORTS

IMPORTS
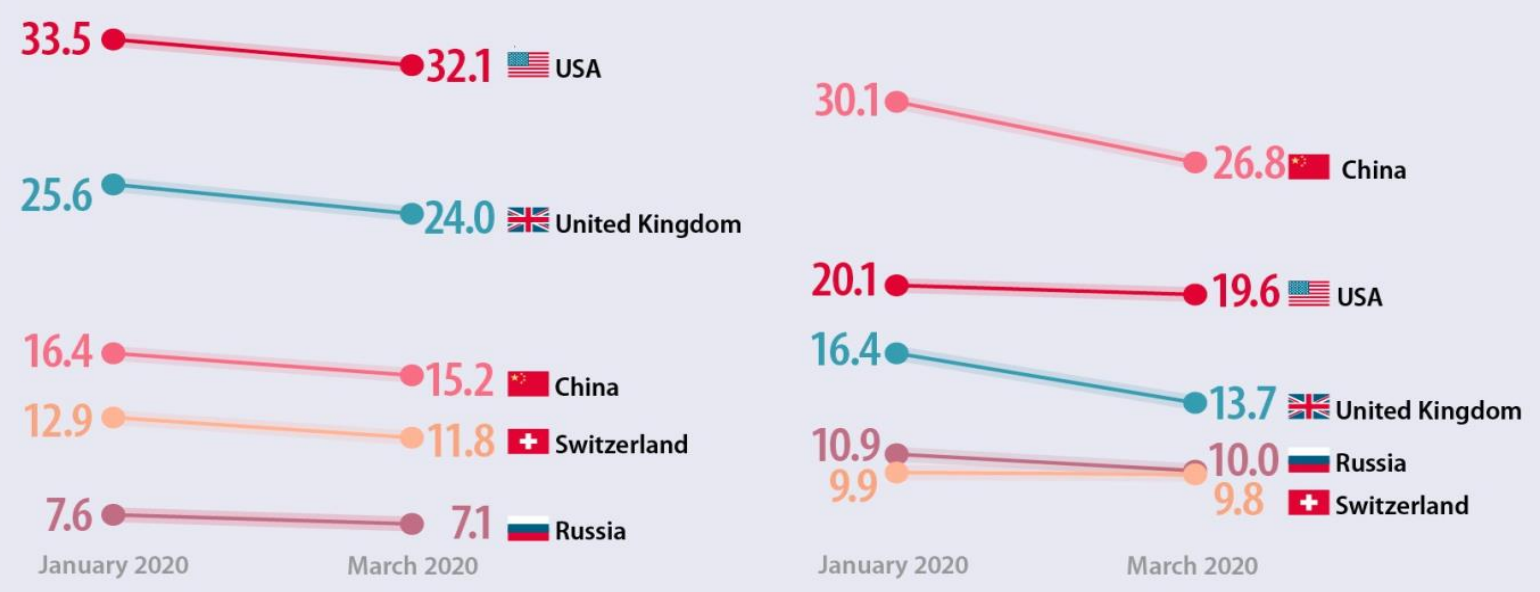

ec.europa.eu/eurostato

The chart below shows the import and export chart of the European Union with 5 main trade partners from January 2020 to March 2020. Smaller decreases were observed in trade with the US (-3.6\%). ), Switzerland (-5.3\%) and Russia (-7.6\%). Turkey's main trading partner among the EU $11(-13.0 \%)$, India $(-11.8 \%)$ and Norway $(-11.7 \%)$ recording the highest decrease in total trade, trade with South Korea just 1.9\% He fell. In March 2020, the EU saw an increase in trade balance with 8 out of 11 main trading partners compared to January 2020, and the highest increases were observed with China $(+2.1$ billion $€)$ and the UK $(+1.2$ billion $€)$.

EU 11 trade balance between the main trading partner, only Turkey (- $€ 0.2$ billion), United States (- $€ 0.9$ billion) and Switzerland (- $€ 1.0$ billion) has declined (europa.eu/eurostat, 2020).

Graphic 5. Payment Methods in International Trade 


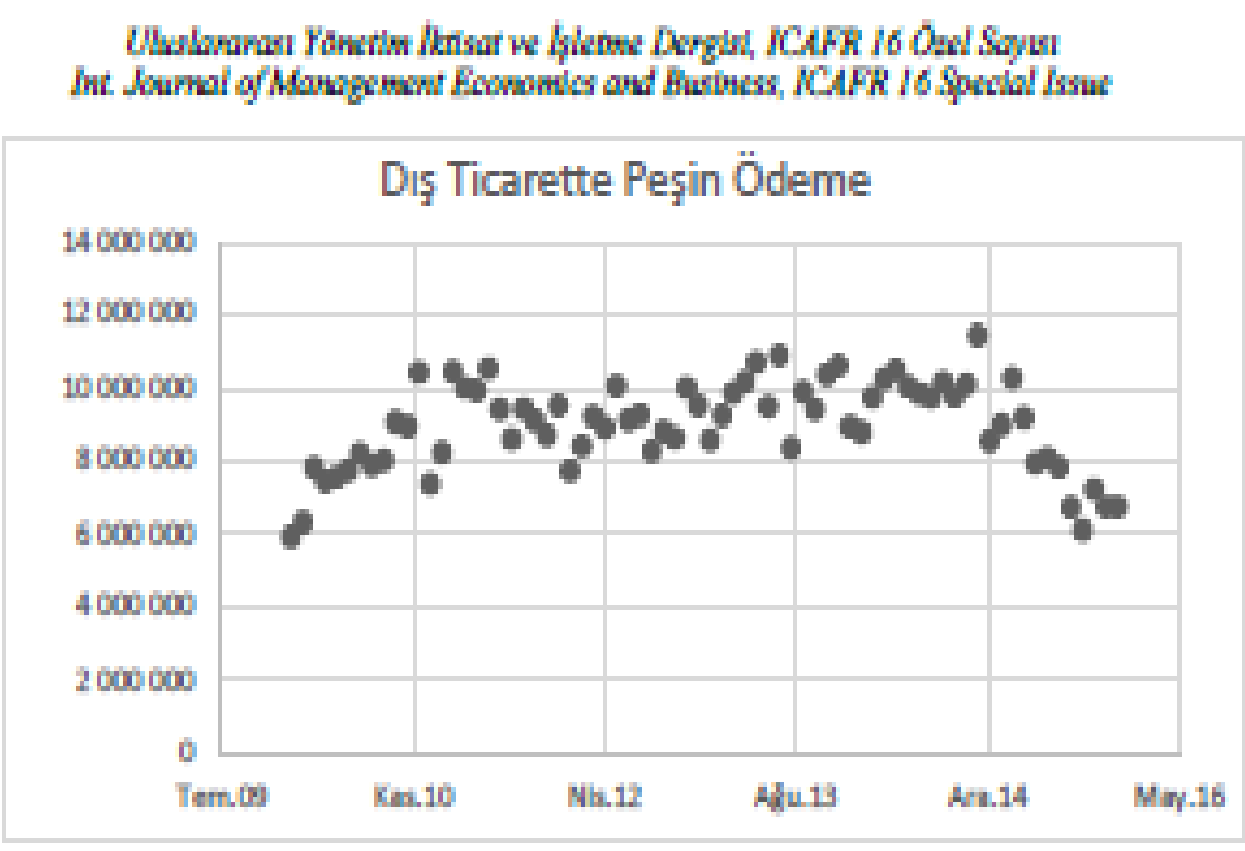

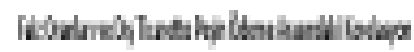

\begin{tabular}{|c|c|c|}
\hline & Fin & Pąn Ddarni \\
\hline Fal & $1 \mathrm{man}$ & \\
\hline Psh burt & ఏ074 & 100 \\
\hline
\end{tabular}

Source: (Payment in Foreign Trade in Turkey

The Changes in the money markets are among the factors affecting import values. There are at least 4 parties in payment methods in foreign trade. These; importer, exporter, bank of the importer, bank of the exporter. Having so many parties in foreign trade will cause the financial statements to be formed as a result of foreign trade transactions to include differences. Banks have added a number of additional features to the credit cards they provide in order to direct consumers shopping with traditional trade to e-commerce. One of these features is virtual credit cards. With this card, which is connected to the main credit card but has different card number, expiration date, and secure code, consumers can complete their shopping within a high security margin by transferring the amount of money they want to buy at the main credit card limits. In addition to these features, card providers such as Master, Visa and Maestro have strict security measures. E-commerce consumers are protected by a process called chargeback. Virtual Pos is software that stores all card information and passwords of virtual stores. Credit card provisioning is performed by transferring data that is secured with security and encryption protocols such as SSL and TLS. Customers' card information, shopping information and digital signature are checked by VPOS. It sends the customer's card information, shopping information and the certificate of the business to the] bank in encrypted form. Bank information is verified and whatever the shopping price from the customer's account is transferred to the bank where the account of the electronic 
commerce business is located by the bank. The most preferred form of payment in exports was the correspondence to goods. Preferred payment types in exports in April 2020: 1 Most exports "Payment Against Goods" (\$ 5 billion 424 million) 2nd Cash Payment "(1 billion 536 million dollars) and“ Documentation Against Documents "(736 million dollars) Looking at the preferred forms of payment in imports .

1. While most imports are made with "Payment Against Goods" (7 billion 330 million dollars), 2nd. . the payment method was followed by "Cash Payment" (2 billion 918 million dollars) and "Term Letter of Credit" ( 823 million dollars). The total foreign trade volume of the companies benefiting from the facilitating foreign trade practices offered by the Ministry of Commerce was 5 billion 841 million Dollars in 2020. ( 2 billion 29 million dollars export, 3 billion 812 million dollars import). It decreases.

\section{RESULTS}

The company has a healthier and safer than face-to-face sales because it expanded its marketing area and promoted its recognition because it provided a $35-40 \%$ discount in retail (B2C- company to customer-) sales for online shopping after the Corona epidemic. is the reason for preference. As of 2017, 3.6 billion, approximately half of the human population, which is approximately 7.5 billion, are internet users. According to the 2016 global B2C ecommerce report published by ecommercefoundation.org, the number of people over 15 is 5,563 billion and $26 \%$ of these people, or 1,436 billion people, have exchanged products or services on the Internet at least once. Global e-commerce transaction volume reached \$2,671 trillion, up $17.5 \%$ in 2016 from \$2,272 trillion in 2015. The group created by ICC has added a new digital economy and digital form of payment and a new form of post-epidemic payment methods. BPO (Bank Payment Obligation) A new form of payment and financing is observed in foreign trade. If the risk increases for the buyer and the seller in terms of payment against goods used in foreign trade, documents against payment, cash, letters of credit, etc., operational difficulty and cost also increase. The last solution produced by the banking system; BPO (Bank Payment Obligation) option. The Bank Payment Obligation system reduces both risk and operational burden and cost

\section{REFERENCES}

(2020). https://www.fundalina.com/2020-yili-global-dijital-raporu/. adresinden alınmıştır

Administration, U. D. (2020). Methods of Payment inInternational Trade. https://www.export-u.com/DOWNLOADS/Payment-Terms-Summary.pdf.

Ağsakal, A. (, ICAFR 16 Özel Sayısı Int. Journal of Management Economics and Business, ICAFR 16 Special Issue). Türkiye'de Dış Ticarette Ödeme Şekilleri. Uluslararası Yönetim İktisat ve İşletme Dergisi, ICAFUluslararası Yönetim İktisat ve İşletme Dergisi, ICAFR 16 Özel Sayısı Int. Journal of Management Economics and Business, ICAFR 16 Special Issue 581 Uluslararası Yönetim İktisat ve İşletme Dergisi, ICAF.

Year 4/ 2020, Volume-4, Issue-4 | WwW.ispecjournal.org 
Bayram, O. (2020). Uluslararası Ticarette Tahsil Esasına Dayalı Ödeme Şekilleri (Collectıon Basıs) Ve Uygulama Adımları. İzmir İktisad Dergisi, İİBDergis, i2019; 2(2): 209-216 .

Birlikleri, O. A. (2020). Dış Ticarette Kullanılan Ödeme Şekilleri Hakkında Bilgi Verebilir misiniz. https://www.oaib.org.tr/tr/bilgi-merkezi-sikca-sorulan-sorular-dis-ticarette-kullanilanodeme-sekilleri-hakkinda-bilgi-verebilir-misiniz.html.

Commerce, I. C. (2020, July ). Guidance paper on the impactof COVID-19 on trade finance transactions subject to ICC https://iccwbo.org/content/uploads/sites/3/2020/04/2020-10-the-impact-of-covid-19.pdf. adresinden alınmıştır

Commerce, I. (2020). https://iccwbo.org/media-wall/news-speeches/digital-trade-standardsinitiative-launches-under-the-umbrella-of-icc/. ttps://iccwbo.org/media-wall/newsspeeches/digital-trade-standards-initiative-launches-under-the-umbrella-of-icc/. adresinden alınmıştır

COVID-19'un AB Uluslararası Mal Ticareti Üzerindeki Etkisi. (2020). https://ec.europa.eu/eurostat/web/products-eurostat-news/-/DDN-20200519-2.

Economic and Social Commission for Asia and The Pacific The Impact and Policy Responsesfor COVID-19 in Asiaandthe Pacific. 1-32. https://www.unescap . org/sites/default/files/COVID\%20_Report_ESCAP.pdf. Erişim Tarihi: 30.04.2020. (2020). www.unescap.org. adresinden alınmıştır

europa.eu/eurostat. (2020). https://ec.europa.eu/eurostat/web/products-eurostat-news/-/DDN20200519-2.

Global Online Payments Industry Report 2020 - Coronavirüs (COVID-19) Salginının Bir Sonucu Olarak Ödeme Davranışı Değişiyor. https://markets.businessinsider.com/news/stocks/global-online-payments-industry-report2020-payment-behavior-is-changing-as-a-result-of-the-coronavirus-covid-19-outbreak1029353095\#.

Görgün, M. R. (2019). Tedarik Zinciri Yönetimi. Ekonomik Araştırmalar I. içinde Akademisyen Yay. .

https://worldef.net/blog/sinirotesi-odeme-yontemleri/.

(2020).

https://worldef.net/blog/sinirotesi-odeme-yontemleri/.

ICC. (2020). https://iccwbo.org/global-issues-trends/banking-finance/icc-digitalisation-oftrade-finance/. adresinden alınmıştır

MC CKinsey Company Finansal, h. (Dü.). (2020). Ödemeler koronavirüs pandemisine nasıl uyum sağlayabilir ve dünyanın uyum sağlamasına nasıl yardımcı olabilir? McKinsey: 
https://www.mckinsey.com/industries/financial-services/our-insights/how-payments-canadjust-to-the-coronavirus-pandemic-and-help-the-world-adapt\#.

Report, G. O. (2020 ). Global Online Payments Industry Report 2020 - Coronavirüs (COVID19) Salgınının Bir Sonucu Olarak Ödeme Davranışı Değişiyor. https://markets.businessinsider.com/news/stocks/global-online-payments-industry-report2020-payment-behavior-is-changing-as-a-result-of-the-coronavirus-covid-19-outbreak1029353095\#.

Türkiye'de Dış Ticarette Ödeme Şekilleri Ve Faiz (Cilt ICAFR 16 Özel Sayısı). Uluslararası Yönetim İktisat ve İşletme Dergisi,.

Yurtsever, H. Y. (2010). Uluslararası Ödeme Şekillerinde Bankalarca Alınan Komisyon . 